\title{
Factors That Shape University Students' Attitudes Towards Academic Research
}

\author{
Leah Li Echiverri ${ }^{1}$, Wanghan Chen ${ }^{2}$, Xinyi Wang ${ }^{2}$
}

${ }^{1}$ College of Liberal Arts, Wenzhou-Kean University, China, ${ }^{2}$ College of Business and Public Management, Wenzhou-Kean University, China.

\begin{abstract}
Students almost always hold different attitudes toward academic research. In order to describe that phenomenon and find out the factors which affected and caused students' different attitudes toward academic research, the researchers investigated Wenzhou-Kean University (WKU) students' attitudes towards the support from the university, research training environment, and their future academic career directions. This descriptive-quantitative study also considered students' attitudes as a variable to measure respondents' understanding and knowledge of academic research, and personal experiences. The sample size of 227 undergraduates represented the cross sectional respondents of the four colleges. Based on data collected by online questionnaires, results showed that most WKU students held positive attitudes toward academic research and are aware of its significance. WKU students did not have enough personal experiences in undertaking research studies. Generally, WKU students realized and acknowledged the significance of academic research in cultivating their inquiry mind and gain better understanding of the research course content. All of the three factors could affect students' attitudes and motivations toward academic research. Faculty mentoring in the research training environment has the strongest influence while on-campus related activities in the support from the university has the lightest influence on WKU undergraduates' attitudes towards research.
\end{abstract}

Keywords: academic research; undergraduate students; university support; future career plans; research training environment. 


\section{Introduction}

Research experiences and skills are crucial for students at any level of education and can benefit them in different perspectives (Ruchina et al., 2015). For researchers themselves, doing research can deepen the understanding of their professional fields and explore the unknown area of their interest, in the long run, it can foster the inquiring spirit and persistence, and improve critical thinking skills. As for a larger scope, research can also promote academic development, benefiting the society someday.

However, though it has a great benefit to take part in academic research for undergraduates, students still hold different attitudes towards research, varying from positive to negative. A study showed that most students are aware of the importance and necessity of research work as part of their university curriculum" (Kozlova \& Atamanova, 2013), but meanwhile, do not recognize the role and significance of research work for their personal and professional development. Also, there is still a small number of students that have neutral or negative attitudes towards academic research (Kozlova \& Atamanova, 2013). It is an interesting phenomenon, and this study tried to describe it and find out its causes.

There are some problems and limitations of our study though. Firstly, we randomly survey the samples of WKU students, the limited resources and costs determined that we cannot cover $100 \%$ students in WKU. Consequently, the results cannot approximately be precise, some deviation and bias might have appeared. Furthermore, some of the participants and the respondents of our questionnaire might provide some ineffective data due to their unserious response, which will affect the validity and reliability of the collected data.

\subsection{Attitudes towards academic research}

Academic research is a basic and important activity in academia (Otieno \& Matoke, 2014) and it is important for undergraduate students to learn the research skills (Kinhead, 2003). Previous research has shown that there are different attitudes towards academic research among undergraduate students (Kozlova \& Atamanova, 2013), which most undergraduate students hold positive attitudes towards research while there are still approximately $1 / 3$ of them belonging to the rest. They analyzed the phenomenon partially caused by students' different understandings about research.

\subsection{Research support from college}

Beerkens points out that the universities' management of research programs will affect the production of academic research (2013). More intensive management can be regarded as a support that will have a positive effect on increasing the undergraduate students' interest in academic research. As a way for the college to support undergraduate research, on-campus academic activities have a positive impact on the attitudes of undergraduate students towards 
research (John \& Creighton, 2011), increasing students' confidence in undertaking research by enriching their research experiences and skills.

Furthermore, library services in college can help students develop their critical thinking skills which are vital in analyzing the information (Silk et al., 2015, p. 153). Different libraries in China have different capacity levels in supporting undergraduate students' academic activities (Xi et al., 2019), and varying levels of library services may lead to different attitudes toward research for undergraduate students.

Financial support from universities plays a crucial role in research (Helene \& Ribeiro, 2011, p. 679). Lacking investments in academic studies and research will lead to the reduction of production and quality of research. Financial support seems like an important factor has an impact on students' attitudes toward research as well. According to Stanford et al., (2017), increasing financial support by universities would increase the number of freshman research participants, meaning that enough financial support from college would make students' attitudes toward research more positive.

\subsection{Research training context}

According to Chumwichan and Siriparp, 2016, the research training environment does not have any direct impact on research interest in graduate students but has a significant indirect influence. As the sub factors "research curriculum" and "student-faculty mentorship" both are instructional research training environments according to the study (Chumwichan \& Siriparp, 2016), they have an indirect effect on students' attitudes toward academic research. It is studied that after taking a research course in the second year, students hold more positive attitudes toward research because they develop more positive opinions of the significance of research and better capability of research (Van der Linden et al., 2015). In addition, faculty mentoring, as a part of the research environment, also positively affects students' attitudes toward academic research, developing their research knowledge and skills (van der Linden et al., 2012, p. 415), as well as their interests on research (Dolan \& Johnson, 2010).

\subsection{Academic and career direction}

Previous research investigated that students are aware of the significance and benefits of conducting academic research on their future careers (Murdoch-Eaton et al., 2010, p. 156). However, different professional fields have broadly different curriculum design, and the more curriculum embedded with research experiences, the more students actively participate in research, leading to students' different attitudes toward academic research (Zimbardi \& Myatt, 2014). Likewise, Goetz et al.'s study (2017) recommended that "provide training as part of the curriculum" (p.16) will be useful to encourage undergraduates to engage in academic research. Furthermore, students who have different postgraduate plans hold different attitudes towards academic research (John \& Creighton, 2011). It was pointed out 
that if an undergraduate student intends to go to graduate school, he/she is more likely to participate in undergraduate research.

\subsection{Conceptual Framework}

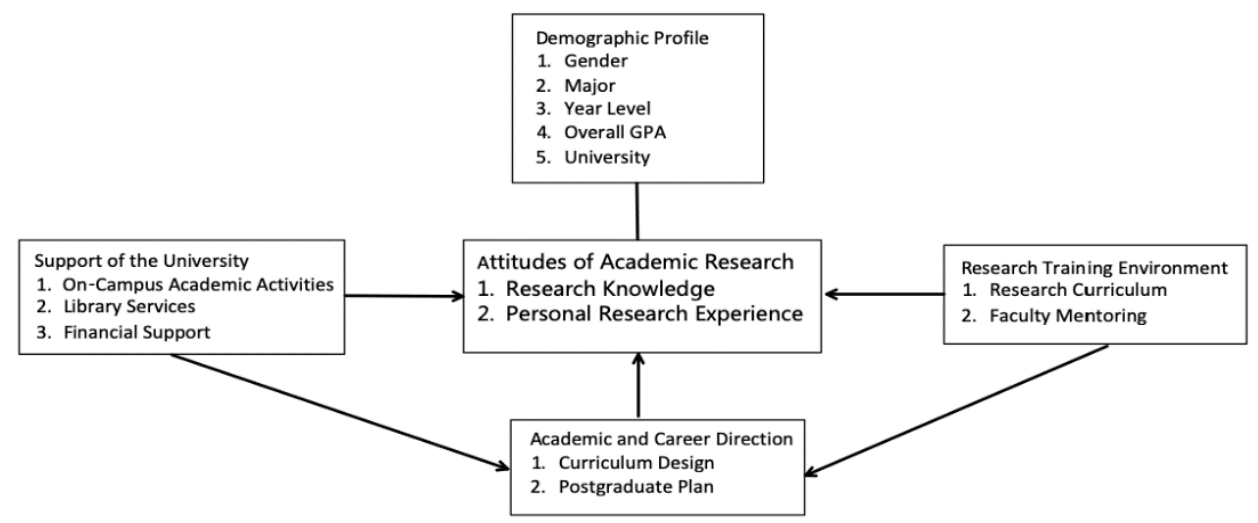

Figure 1. Factors Shaping Undergraduates' Attitudes towards Academic Research

\section{Methodology}

Descriptive-quantitative approach was used in the study to describe the factors that shape undergraduates' attitudes towards academic research. The study was conducted at WenzhouKean University, a joint Chinese-American university in China, during the academic year 2018-2019. WKU students who are mostly composed of Chinese nationals adapt to the American educational system.

Cross-sectional design was used to represent gathered data collected from the four colleges. Returns from the distributed questionnaire were received from 227 respondents approximately representing $10.09 \%$ of the study population that consisted of WKU undergraduate students. Of the 227 respondents, 70 (30.84\%) and 157 (69.16\%) respondents were male and female respectively. Respondents' distribution as to year level were as follows: $11.01 \%$ (25) of respondents are freshmen; $44.49 \%$ (101) are sophomores; $27.75 \%$ (63) seniors and $16.74 \%$ (38) juniors.

This study used online questionnaires posted through the survey website named Wenjuanxing. The link was shared on social media such as QQ or Wechat for target respondents to access and respond. The questionnaire used the five-point attitudinal Likert scale to measure participants' attitudes towards academic research and the related factors shown on the conceptual framework (Figure 1). A 5-point Likert scale was used to indicate respondents' 
attitudes. Numbers closer to 1 represented strong disagreement (SD).and numbers closer to 5 represented strong agreement.

\section{Results and Discussions}

\subsection{Attitudes toward academic research}

WKU students' level of understanding and knowledge about academic research is generally "Above Average" according to the total $(\bar{X}=3.60)$ based on the 5-point Likert scale (Table 1). More specifically, $70.48 \%$ of respondents agreed that conducting research is significant $(\bar{X}=$ 3.81), which can be described as “Above Average". Table 2 presents students' opinions on the significance of research in which "cultivate my inquiry spirit" $(71.81 \%)$ ranked first and "help me understand the course content" (69.6\%) ranked second. The $64.76 \%$ of the respondents agreed that "the significance of research would encourage them to conduct research". Furthermore, most of the participants $(66.96 \%)$ responded that they had conducted research and had more or less research experiences, and those who have had research experience agreed that research experiences would encourage them to conduct research again.

Table 1. Level of understanding and knowledge about academic research.

\begin{tabular}{clc}
\hline & \multicolumn{1}{c}{ Opinions } & Mean of 5-point Likert Scale \\
& $\begin{array}{l}\text { I understand and know well about how to } \\
\text { undertake a study. }\end{array}$ & 3.28 \\
\cline { 2 - 3 } $\begin{array}{c}\text { Level of } \\
\text { understanding and } \\
\text { knowledge about } \\
\text { academic research }\end{array}$ & $\begin{array}{l}\text { I believe that conducting academic } \\
\text { research is significant. }\end{array}$ & \multirow{2}{*}{3.81} \\
\cline { 2 - 3 } & $\begin{array}{l}\text { Significance of research (Table2) will } \\
\text { encourage me to undertake research. }\end{array}$ & \\
\hline
\end{tabular}


Table 2. Top 5 significance of research based on students' opinions.

\begin{tabular}{clc}
\hline Ranking & Students' Opinions on the Significance of Academic Research & $\begin{array}{c}\text { Percentage of } \\
\text { students } \\
\text { support }\end{array}$ \\
\hline 1 & Research cultivates my inquiry spirit. & $71.81 \%$ \\
2 & Research can help me understand course content. & $69.60 \%$ \\
4 & Research fosters my persistence. & $57.27 \%$ \\
5 & Research can help me in my professional career. & $56.83 \%$ \\
\hline
\end{tabular}

\subsection{Research support from University}

From the perspectives of WKU undergraduates, more than half $(53.30 \%)$ of the respondents thought on-campus academic research activities of their university were effective $(\bar{X}=3.59)$, and $59.03 \%$ agreed that the efficiency of on-campus academic research activities would more or less influence their attitudes towards research. In evaluating the level of library services of $\mathrm{WKU}, 61.98 \%$ of the evaluations were positive, and the majority of the respondents $(61.23 \%)$ believed that the library services efficiency would significantly support them to undertake academic research $(\bar{X}=3.67)$. The level of financial support for research was evaluated relatively less effective than that of on-campus research activities because less than half of the respondents $(48.02 \%)$ thought it was supportive, but most respondents $(63.43 \%)$ agreed that college support on research was significant and could influence their attitudes towards research $(\bar{X}=3.67)$, which was interpreted as "Above Average".

\subsection{Research training environment}

As for the research training environment, respondents evaluated that the level of "an overall background and knowledge about research" the college research curriculum offered was "Above Average", and 74.89\% of them consider college research curriculum as an important factor that influence their attitude towards research $(\bar{X}=3.93)$. On another aspect, "studentfaculty research mentorship" was a common relationship among researchers at WKU, which was also evaluated as "Above Average" $(\bar{X}=3.99)$. The $75.78 \%$ respondents admitted that student-faculty mentorship can make them more confident in research. 


\subsection{Academic and career direction}

In terms of academic and career direction, $71.81 \%$ respondents agreed that characteristics of their profession would impact their decision about whether to undertake research or not, which means that different academic directions will influence undergraduates' attitudes toward research. About $56.83 \%$ of the respondents who planned to apply for a graduate program either domestic or abroad after graduation from WKU held more positive attitudes. Also, $71.8 \%$ of respondents thought their post-graduate plans would influence their attitudes towards research.

\subsection{Overview of the three factors that shape undergraduates' attitudes towards research}

Generally, the results showed that among the three factors that contributed to shaping undergraduates' attitudes towards research, the research training environment ranked most significant $(\bar{X}=3.96)$, while the factor of research support from university ranked least significant $(\bar{X}=3.64)$. In addition, faculty mentoring in the factor of the research training environment has the highest mean $(\bar{X}=3.99)$ among all the sub factors.

Table 3. Means Factors shaping undergraduates' attitudes towards academic research

\begin{tabular}{llcl}
\multicolumn{1}{c}{ Factors } & \multicolumn{1}{c}{ Sub factors } & Mean of 5-point Likert Scale \\
\hline & On-campus research activities & 3.59 & 3.64 \\
$\begin{array}{l}\text { Research support } \\
\text { from University }\end{array}$ & Library services & 3.67 & 3.81 \\
& Financial support & 3.67 & \\
\hline $\begin{array}{l}\text { Academic and } \\
\text { career direction }\end{array}$ & Curriculum design & 3.81 & 3.96 \\
& Postgraduate plans & 3.93 & \\
\hline $\begin{array}{l}\text { Research training } \\
\text { environment }\end{array}$ & Research curriculum & 3.99 \\
\hline
\end{tabular}




\subsection{Implications and Conclusion}

Research reported that faculty mentoring in the research training environment has the strongest influence on WKU undergraduates' attitudes towards research. The implication of this finding suggests the strengthening of faculty mentoring to enhance not only students' confidence in conducting research but also promote students' research experiential learning.

Research support from university on shaping students' attitudes is the lightest amongst the three factors. WKU is advised to organize more on-campus research activities, offer efficient library services and expand financial support on students' research related experiences.

WKU students widely recognize the merits of research that heighten to cultivate students' inquiry spirit and gain deeper understanding of the research course content. Hence, the conglomeration of these factors contribute to the shaping of their positive attitudes towards academic research with a clear perception of the significance of research and relatively above average knowledge about conducting research.

\section{References}

Beerkens, M. (2013). Facts and fads in academic research management: The effect of management practices on research productivity in Australia. Research Policy, 42(9), 1679-1693. doi:10.1016/j.respol.2013.07.014

Chumwichan, S., \& Siriparp, T. (2016). Influence of research training environment on research interest in graduate students. Procedia-Social and Behavioral Sciences, 217, 950-957.

Dolan, E. L., \& Johnson, D. (2010). The undergraduate-postgraduate-faculty triad: unique functions and tensions associated with undergraduate research experiences at research universities. CBE_Life Sciences Education, 9(4), 543-553.

Goetz, S. C., Romero, M. J., \& Robertson, M. F. (2017). Perspectives and researcher experiences of undergraduate research. Journal of Applied Sciences and Arts, 1(3), 7.

Helene, A. F., \& Ribeiro, P. L. (2011). Brazilian scientific production, financial support, established investigators and doctoral graduates. Scientometrics, 89(2), 677.

John, J., \& Creighton, J. (2011). Researcher development: the impact of undergraduate research opportunity programmes on students in the UK. Studies in Higher Education, 36(7), 781-797.

Kinkead, J. (2003). Learning through inquiry: An overview of undergraduate research. New Directions for Teaching and Learning, 93, 5-17.

Kozlova, N. V., \& Atamanova, I. V. (2013). The development of undergraduates motivation for research work. Procedia-Social and Behavioral Sciences, 93, 498-502.

Murdoch-Eaton, D., Drewery, S., Elton, S., Emmerson, C., Marshall, M., Smith, J. A., ... \& Whittle, S. (2010). What do medical students understand by research and research skills? Identifying research opportunities within undergraduate projects. Medical Teacher, 32(3), e152-e160. 
Otieno, D. O., \& Matoke, V. B. (2014). Social media as tool for conducting academic research. International Journal, 4(1).

Ruchina, A. V., Kuimova, M. V., Polyushko, D. A., Sentsov, A. E., \& Jin, Z. X. (2015). The role of research work in the training of master students studying at technical university. Procedia-Social and Behavioral Sciences, 215, 98-101.

Silk, K., Perrault, E., Ladenson, S., \& Nazione, S. (2015). The effectiveness of online versus in-person library instruction on finding empirical communication research. The Journal of Academic Librarianship, 41(2), 149-154. doi:10.1016/j.acalib.2014.12.007

Stanford, J. S., Rocheleau, S. E., Smith, K. P., \& Mohan, J. (2017). Early undergraduate research experiences lead to similar learning gains for STEM and Non-STEM undergraduates. Studies in Higher Education, 42(1), 115-129.

Van der Linden, W., Bakx, A., Ros, A., Beijaard, D., \& Van den Bergh, L. (2015). The development of student teachers' research knowledge, beliefs and attitude. Journal of Education for Teaching, 41(1), 4-18. doi:10.1080/02607476.2014.992631

Van der Linden, W., Bakx, A., Ros, A., Beijaard, D., \& Vermeulen, M. (2012). Student teachers' development of a positive attitude towards research and research knowledge and skills. European Journal of Teacher Education, 35(4), 401-419.

Xi, Q., Wu, W., Ji, J., Zhang, Z., \& Ni, F. (2019). Comparing the level of commitment to indepth reference and research support services in two sets of Chinese universities. Science \& Technology Libraries, 1-20.

Zimbardi, K., \& Myatt, P. (2014). Embedding undergraduate research experiences within the curriculum: a cross-disciplinary study of the key characteristics guiding implementation. Studies in Higher Education, 39(2), 233-250. 